\title{
Dampak Makro Ekonomi dan Financial Performance Terhadap Market Share Perbankan Syari’ah di Indonesia
}

\author{
Muh. Khairul Fatihin', Eko Siswahto ${ }^{2}$, Sulistya Rusgianto ${ }^{3}$, dan \\ Nizar Hosfaiqoni. Hadi ${ }^{4}$ \\ Magister Sains Ekonomi Islam, Fakultas Ekonomi dan Bisnis, Universitas Airlangga ${ }^{124}$ \\ Departemen Ekonomi Syariah, Fakultas Ekonomi dan Bisnis, Universitas Airlangga ${ }^{3}$ \\ Email: Muh.khairul.fatihin-2018@pasca.unair.ac.id
}

\begin{abstract}
Abstrak: Islamic banking market share is the biggest contributor on the development of the Islamic financial market share. This study aims to comprehensively examine the sharia banking market share growth in short-term and long-term dynamic interactions. The independent variables used in this study are inflation, industrial production index (IPI), intrest rate, Return of Assets (ROA) and financing to Deposite Ratio (FDR). The method used is the Autoregressive Distributed Lag Model (ARDL) with monthly data from 20112018. The results of this study indicate that interest rates have a significant negative effect on Islamic banking market share in the short and long term. Meanwhile, inflation, ROA, FDR have a positive effect on the sharia banking market share in the short term. IPI's industrial production index as a proxy for domestic product (gross domestic product) has no short-term and long-term impact. The results of this study have important implications for the central bank and the banking sector.
\end{abstract}

Keyword: Market Share, intrest rate, Inflation, ROA, FDR.

\begin{abstract}
Abstrak: Market share perbankan syariah adalah salah satu kontributor terbesar terhadap kemajuan market share keuangan islam. Penelitian ini bertujuan untuk mengkaji secara komprehensif pertumbuhan market share perbankan syari'ah dalam interaksi dinamik jangka pendek dan jangka panjang. Variable independen yang digunakan dalam penelitian ini adalah inflasi, industrial production index (IPI), intrest rate, Return of Asset (ROA) dan financing to Deposite Ratio (FDR). Metode yang digunakan adalah Autoregressive Distributed Lag Model (ARDL) dengan data bulanan dari tahun 2011-2018. Hasil penelitian ini menunjukkan bahwa Suku bunga berpengaruh negatif yang signifikan terhadap market share perbankan syariah dalam jangka pendek dan jangka panjang. Sementara itu, Inflasi, ROA, FDR Berpengaruh positif terhadap market share perbankan syari'ah dalam jangka pendek. Industrial production index IPI sebagai proxy produk domestic product (gross domestic product) tidak memiliki dampak jangka pendek dan jangka panjang. Hasil penelitian ini mempunyai implikasi yang penting kepada bank sentral dan pihak perbankan.
\end{abstract}

Keyword: Market Share, intrest rate, Inflasi, ROA, FDR.

\section{PENDAHULUAN}


Penelitian ini bertujuan untuk mengkaji pertumbuhan market share perbankan syari'ah dalam jangka pendek dan jangka panjang. Karena perbankan syari'ah adalah salah satu kontributor pertumbuhan market share keuangan syari'ah dan Pemerintah indonesia telah menetapkan target market share keuangan syari'ah sebesar 20\% pada tahun 2023 (Deputi Bidang Ekonomi, 2019-2023). Market share perbankan syari'ah memiliki peran yang sangat vital dalam memajukan keuangan syari'ah di Indonesia. Perbankan syari'ah membutuhkan usaha ekstra melalui sinergi perbankan syariah dan dukungan kebijakan yang mendukung kemajuan perbankan syariah. Pengalaman sebelumnya menunjukkan bahwa Krisis ekonomi yang terjadi Pada tahun 2008 mendorong pemerintah untuk membuat Undang-Undang baru tentang industri perbankan Islam di Indonesia (UU No. 21 tahun 2008). Para pembuat kebijakan di Indonesia telah menetapkan tujuan Industri perbankan syariah harus mencapai pangsa pasar 5\% pada tahun 2008. Pemerintah optimis karena pada tahun tersebut bank syariah tetap eksis meskipun diterpa krisis ekonomi dunia. Namun, target ini akhirnya tercapai pada akhir 2016. Butuh beberapa tahun untuk mencapai target pangsa pasar 5\% di Indonesia. target pangsa pasar 5\% akhirnya tercapai setelah konversi Bank Aceh menjadi syariah penuh bank (Arif, 2018).

Gambar 1. Pertumbuhan market share perbankan syari'ah

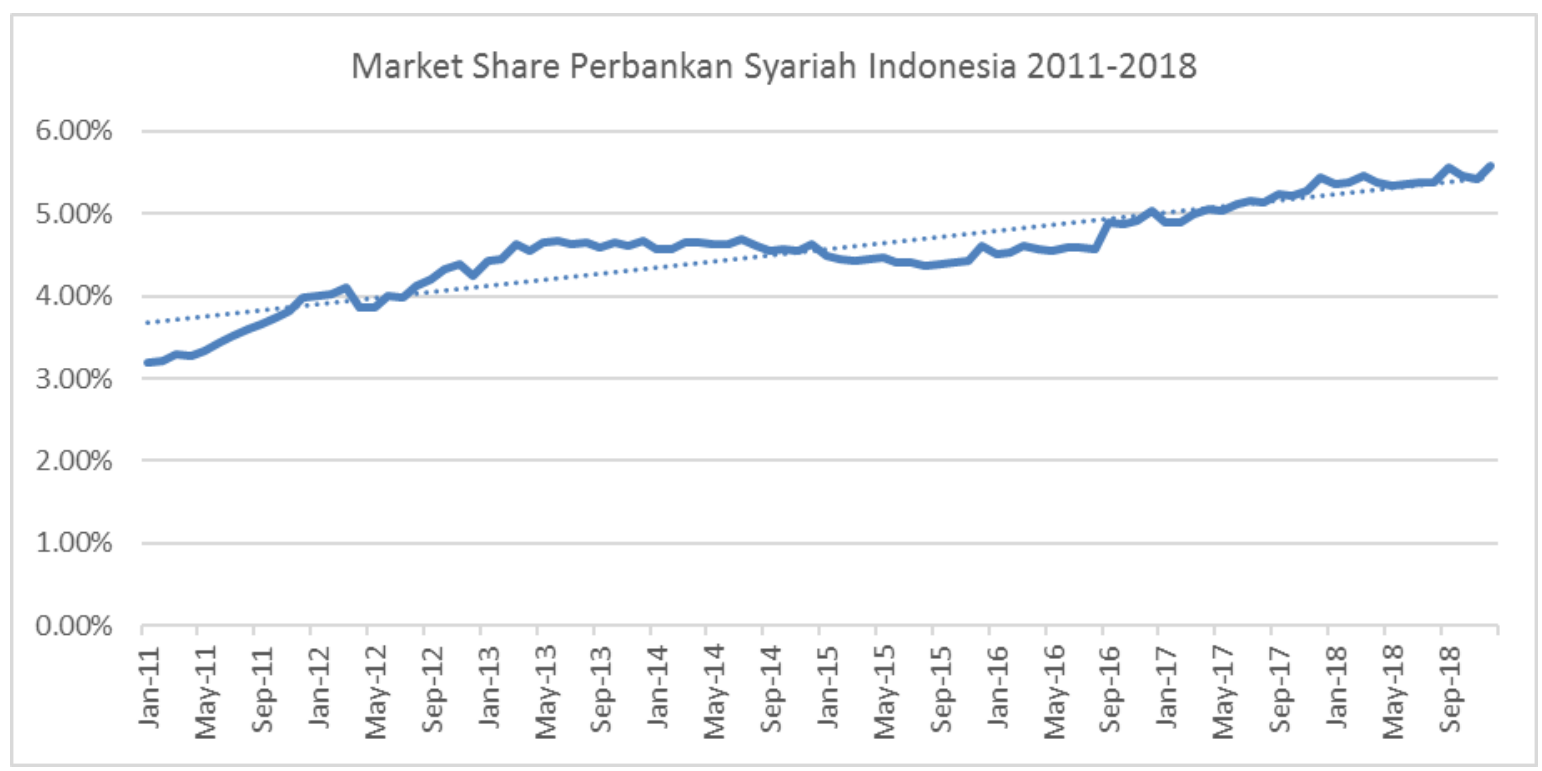

Sumber: statistic OJK

Berdasarkan grapik diatas, pangsa pasar perbankan syariah di Indonesia mengalami peningkatan dan penuruan (fluktuasi) dengan peningkatan pasar yang sedikit dari tahun ke tahun. Pangsa pasar (market share) bank syariah di Indonesia saat ini tertinggal jauh dari negara lainnya seperti Malaysia dan Singapura (Sari et al., 2016), (Wouters, 2009). Pada saat ini Indonesia masih bercokong diposisi kesembilan dan cendrung menjadi penonton dalam pengembangan ekonomi syariah. Ada beberapa masalah lain yang dihadapi oleh perbankan syariah seperti Regulasi yang kurang mendukung berkembangnya perbankan syariah padahal faktor penentu kemajuan perbankan syariah disetiap negara adalah regulasi pemerintah (Bitar, 2018). Seperti di Malaysia dan Iran dimana negara Iran memiliki $100 \%$ pangsa pasar perbankan syariah karena didukung oleh kebijakan 
pemerintah yang pro terhadap perbankan syariah. Hal ini menunjukkan bahwa kemajuan perbankan syariah sangat ditentukan oleh regulasi pemerintah sehingga untuk memajukan perbankan syariah pemerintah harus menciptakan iklim perbankan syariah yang baik (Bitar, 2018).

Market share adalah ukuran kesukesan dan kepercayaan masyarakat terhadap perbankan syari'ah. Dengan meningkatnya market share perbankan syariah maka kontribusi perbankan syari'ah akan semakin besar dalam perekonomian. Penelitian market share termasuk penelitian yang masih sedikit. Dengan meneliti market share perbankan syariah, pengaruh variable makro dan performa perbankan syariah dapat dianalisis secara komprehensif sekaligus dapat mengukur kesuksesan dan kepercayaan stakeholder terhadap perbankan syari'ah.

\section{KAJIAN TEORI}

Market Share adalah persentase dari keseluruhan pasar untuk sebuah kategori produk atau servis yang telah dipilih dan dikuasai oleh satu atau lebih produk atau servis tertentu yang dikeluarkan sebuah perusahaan dalam kategori yang sama (Thoriq, 2007). Dalam pengertian yang lebih sempit Market share adalah perbandingan volume penjualan industri baik dalam unit maupun dalam rupiah. Jadi pangsa pasar atau market share adalah keseluruhan pasar yang berhasil dikuasai oleh perusahaan untuk menjual produk yang ditawarkan. Oleh karena itu, kegiatan perusahaan yang dilaksanakan untuk meningkatkan market share harus diarahkan kepada pelanggan atau calon pelanggan agar menarik mereka menggunakan jasa perbankan. Kekuatan bank direfleksikan dengan pangsa pasar yang dikuasainya (Hendra dan Hartomo, 2017). Pangsa pasar yang luas menunjukkan bahwa bank dapat berpartisipasi dalam kompetisi dengan bank lainnya. Bank dengan pangsa pasar kecil harus memiliki strategi pasar yang efektif untuk bersaing dengan bank lainnya sehingga tetap kompetitif dalam persaingan, disamping itu juga bank dengan pangsa pasar yang luas hendaknya memberikan ruang bagi bank lain untuk meningkatkan pangsa pasar dengan tujuan untuk membangun kerjasama dalam mendorong kemajuan ekonomi. Pangsa pasar dapat menjadi motivasi bagi perusahaan untuk meningkatkan kualitas usahanya. Pangsa pasar yang tinggi memiliki kemampuan yang lebih besar dalam memberikan pelayanan kepada konsumen sehinga penjualan produk semakin tinggi yang menghasilkan keuntungan bagi perusahaan (Naylah, 2010). Pangsa pasar adalah kekuatan bagi perusahaan yang memberikan pengaruh untuk mempengaruhi pasar. Ketika nilai pangsa psar tinggi maka kekuatan untuk mempengaruhi pasar sangat kuat. Dengan demikian pangsa pasar adalah indikator kuat kekuatan pasar.

Selain itu, Pangsa pasar adalah persentase pasar yang diperhitungkan secara khusus. Salah satu yang utama penentu profitabilitas bisnis adalah pangsa pasar. Dalam sebagian besar keadaan, perusahaan yang memiliki pangsa pasar tinggi jauh lebih menguntungkan dibandingkan dengan perusahaan yang pangsa pasarnya lebih kecil. Perusahaan dapat membuat target penjualan sebagai dasar perusahaan dalam melakukan ekspansi pasar atau akuisisi saham. Marketer harus mampu menerjemahkan target penjualan ke pangsa pasar karena ini akan menunjukkan apakah perkiraan akan dicapai dengan bertumbuhnya pasar atau menangkap pangsa dari pesaing. Pangsa pasar menjadi salah satu indikator keberhasilan organisasi yang paling penting. Pangsa pasar sering digunakan untuk menggambarkan posisi perusahaan dalam sektor industrinya. Implikasinya biasanya 
bahwa semakin besar pangsa pasar, semakin sukses perusahaan. Mengemukakan bahwa pangsa pasar dapat menjadi penentu penting dari profitabilitas dalam jangka menengah dan panjang. Pangsa pasar yang besar adalah hadiah untuk memberikan nilai yang lebih baik dan cara mewujudkan biaya yang lebih rendah. Dalam sebagian besar keadaan, perusahaan yang telah mencapai pangsa pasar yang mereka layani jauh lebih menguntungkan daripada saingan pangsa pasar yang lebih kecil. Hubungan antara pangsa pasar dan profitabilitas ini telah diakui oleh para eksekutif dan konsultan perusahaan, dan hal ini jelas ditunjukkan dalam hasil penelitian kami selama lima belas tahun terakhir. Pentingnya pangsa pasar juga diakui indikator utama pertumbuhan industry. Termasuk dalam hal ini adalah industry perbankan syariah. Ini tidak mengherankan, karena perusahaan-perusahaan dengan status pemimpin pasar cenderung memperoleh profitabilitas dari kemampuan skala ekonomis mereka serta branding yang mereka miliki. Sebagian besar perusahaan memiliki tujuan utama meningkatkan profitabilitas dalam jangka pendek dan memperbesar pangsa pasar dalam jangka menengah dan panjang. Peningkatan profitabilitas dapat dihasilkan dari mengejar peluang di pasar yang dinamis dan berkembang daripada terus bersaing di pasar yang matang. Jadi, sementara pangsa pasar tampak penting, dalam kenyataannya, perusahaan harus mencari keselarasan jenis pasar dengan penawaran produk sebagai sarana keunggulan kompetitif yang berkelanjutan.

Adapun mamfaat yang didapatkan oleh bank dalam meningkatkan pangsa pasarnya yaitu sebagai berikut:

a. Perusahaan mendapatkan keuntungan daripada pesaing lainnya.

b. Perusahaan akan tumbuh lebih cepat.

Adapun rumus market share yaitu sebagai berikut :

$$
\text { market share }=\frac{\text { Islamic bank total assets }}{\text { Indonesia banks total assets }} \times 100 \%
$$

Return On Assets (ROA). Rasio yang digunakan untuk mengukur profitabilitas bank. Rasio Profitabilitas adalah rasio yang menunjukkan hasil keseluruhan aktivitas yang dilakukan oleh bank (Houston, 2004). Menurut Return On Assets (ROA) digunakan untuk mengukur manajemen bank dalam memperoleh keuntungan (laba) secara keseluruhan (Supriyanti, 2009). Return On Assets (ROA) dijadikan sebagai indikator kinerja keuangan. Kinerja keuangan yang semakin baik menunjukkan kemampuan bank dalam menghasilkan keuntungan dalam kegiatan operasionalnya. ROA merupakan rasio yang digunakan untuk mengukur kemampuan perusahaan dalam menghasilkan laba (Bankir Indonesia 2015). ROA memberikan gambaran bagaimana efisiensi perusahaan dalam menggunakan aktiva untuk menghasilkan laba. Rasio ROA dapat salah interpretasi apabila pada neraca terdapat sejumlah aktiva dengan nilai jauh lebih rendah dari nilai pasar. Selain itu, agar memberikan angka yang benar, periode waktu neraca dan rugi laba harus sama, artinya laba harus disetahunkan apabila belum mencapai 12 bulan. Rasio profitabilitas mengukur kemampuan perusahaan menghasilkan keuntungan pada tingkat penjualan, aset dan modal saham tertentu (Temewu dan Stanly, 2014). Rasio profitabilitas mengindikasikan keuntungan penjualan atas suatu produk atau jasa dan Rasio profitabilitas juga mengindikasikan keuntungan yang didapatkan melalui investasi (Yudiana, 2014). Hal yang menarik adalah efisiensi manejemen perbankan juga diukur melalui Return on Asset (ROA). Perhitungan Return on Asset dilakukan dengan membagi netto pada tahun tertentu 
terhadap total aset yang dimiliki oleh bank tersebut. Return on Asset menunjukkan kompetensi bank dalam mengelola aktiva secara efektif sehingga menghasilkan keuntungan. Penggunaan ROA bertujuan untuk mengukur efisiensi kinerja bank dalam mengelola asetnya (Purboastuti dkk., 2015).

Dalam analisis laporan keuangan, rasio ini paling sering disoroti, karena mampu menunjukkan keberhasilan perusahaan menghasilkan keuntungan. ROA mampu mengukur kemampuan perusahaan manghasilkan keuntunganpada masa lampau untuk kemudian diproyeksikan di masa yang akan datang. Assetsatau aktivayang dimaksudadalah keseluruhan harta perusahaan, yang diperoleh dari modal sendiri maupun dari modal asing yang telah diubah perusahaan menjadi aktiva-aktiva perusahaanyang digunakan untuk kelangsungan hidup perusahaan. Rasio ROA menilai kualitas pendapatan atau laba yang diperoleh bank harus memperhatikan pertama, tingkat laba, seterusnya komposisi operasional yang menghasilkan laba tersebut, kecenderungan dan tren dibandingkan periode lalu, serta stabilitas dan kesinambungan dari perolehan laba. Bagi manajemen bank, kualitas laba menjadi tolok ukur utama dalam menilai kinerja manajemen dalam mengendalikan bank. Ketika berhasil memperolah tingkat laba yang baik, bank dapat mempunyai kekuatan yang lebih besar untuk mendukung pengembangan operasional, menunjang pertumbuhan aset dan memperbesar kemampuan permodalan. Dengan demikian, para deposan bank sebagai sumber dana bank mempunyai rasa aman yang lebih tinggi berhubungan bisnis dengan bank, dan pemegang saham memperoleh imbal hasil sesuai dengan harapan. Melalui dividen atau capital gain. Sebaliknya, apabila bank tidak mampu menghasilkan laba dengan kualitas baik, kemungkinan bank tidak akan mampu memenuhi kebutan perkreditan masyarakat (Ikatan Bankir Indonesia, 2016).

Suku Bunga. Suku bunga rendah di seluruh dunia menjadi sumber keprihatinan bagi sektor perbankan (Janakiraman, 2019). Suku bunga ini dapat digolongkan sebagai tingkat bunga nominal dan riil (Godspower, 2012). Tingkat bunga nominal, yang tidak mempertimbangkan inflasi, adalah rasio jumlah bunga pinjaman kepada jumlah uang yang dipinjamkan. Di sisi lain, tingkat bunga riil, yang mempertimbangkan inflasi, adalah diukur dalam hal daya beli pemberi pinjaman dengan efek Fisher, menunjukkan hubungan antara dua suku bunga. Konsep utama dari tingkat suku bunga riil adalah menilai tingkat suku bunga sekaligus mengukur tingkat pendapatan yang telah dikurangi inflasi. Boediono berpendapat bahwa Suku Bunga merupakan biaya pertukaran antara uang masa sekarang dan uang masa nanti. Pemerintah harus hati-hati dalam menaikkan suku bunga. Tingginya suku bunga akan berdampak membebani dunia usaha dalam memenuhi kewajiban bunga atau hutang. Idealnya tingkat suku bunga tidak terlalu tinggi dan tidak terlalu rendah sehingga dapat menguntungkan pihak perbankan dan dunia usaha. Bank dan perusahaan mendapatkan profit dari suku bunga yang normal. Suku bunga tergantung pada banyak faktor. Menurut penelitian sebelumnya, ada enam faktor utama yang memengaruhi suku bunga: penawaran dan permintaan kredit; persaingan di pasar pinjaman; dan faktor ekonomi seperti inflasi, ekspektasi investor, kebijakan moneter pemerintah dan ketidakpastian. Dampak langsung risiko suku bunga terhadap konstruksi Pergerakan suku bunga terkait erat dengan siklus bisnis suatu ekonomi dan sedang dipengaruhi oleh biaya modal dan perilaku investasi perusahaan. Jadi, suku bunga adalah indikator tren pasar dan dianggap sebagai penentu utama keputusan perusahaan terlepas dari sifat bisnisnya dari suatu organisasi, risiko tingkat bunga (IRR) akan berdampak langsung pada organisasi 
seperti mempengaruhi keputusannya tentang investasi, pembayaran dividen, laba, bunga investasi, biaya peluang dan pembiayaan (Bulski, 2013)

Suku bunga ditentukan berdasarkan preferensi dan sumber pinjaman para pelaku ekonomi di pasar. Suku bunga (IRR) akan berdampak langsung pada perbankan seperti mempengaruhi keputusannya tentang investasi, pembayaran dividen, laba, bunga investasi, biaya peluang dan pembiayaan (Bulski, 2013). Suku bunga dipengaruhi perubahan daya beli uang, suku bunga pasar atau suku bunga yang disesuaikan dengan keadaan dan waktu. Di sisi lain juga dalam hal pinjaman dan pemberian pinjaman, suku bunga dipengaruhi acuan pengusaha berdasarkan pilihan realitas atau imajiner antara alternatif-alternatif, kemungkinan berdasarkan kesenangan, kepuasan, pemenuhan, kegunaan yang ada. Bank sering menetapkan suku bunga terselubung yaitu suku bunga tinggi dengan tujuan untuk menarik peredaran uang dari masyarakat sehingga tabungan atau deposito bank semakin tinggi. Implikasi yang terjadi adalah masyarakat lebih memilih menabung dari pada menggunakannya pada sector rill atau produktif. Akan tetapi suku bunga yang rendah akan memicu peredaran uang yang semakin luas karena masyarakat mencari keuntungan melalui sector produktif dengan menginvestasikan atau memproduksi barang dan jasa. Singkatnya suku bunga yang tinggi menguntungkan depositor untuk menabung dananya $d$ bank dan suku bunga yang rendah akan mengarahkan masyarakat untuk menginvestasikan danya pada sector riil. Suku bunga yang mempengaruhi tingkat peredaran uang di masyarakat menjadikannya sebagai alat untuk mengontrol inflasi. Semakin tinggi tingkat bunga, maka keinginan untuk melakukan investasi juga semakin kecil, alasannya adalah seorang pengusaha akanmenambah pengeluaran investasinya apabila keuntungan yang diharapkan dari investasi tersebut lebih besar dari tingkat bunga yang harus di bayarkan untuk dana investasi tersebut sebagai ongkos untuk penggunaan dana (cost of capital).

Inflasi. Inflasi diartikan sebagai meningkatnya harga-harga secara terus-menerus. Menurut Boediono inflasi adalah kenaikan harga-harga yang berjalan secara kontinu dalam rentang waktu tertentu (Julianti 2013). Inflasi menyebabkan kenaikan harga secara general yang menyebabkan kenaikan harga secara meluas. Kenaikan harga satu barang disebut inflasi apabila mempengaruhi kenaikan harga bagai barang-barang lainnya seperti kenaikan BBM akan secara lansung direspon dengan peningkatan harga barang komoditas dan barang lainnya. Adapun 3 faktor yang menyebabkan terjadinya Inflasi yaitu pertama, tekanan penawaran (cost push inflation). Inflasi ini terjadi disebabkan terjadinya pelemahan nilai tukar, pengaruh inflasi negara-negara partner dagang, intervensi pemerintah terhadap harga-harga komoditi, dan terjadinya pengaruh negatif karena gangguan distribusi atau bencana alam. Kedua, Target inflasi. Perilaku masyarakat dan pelaku ekonomi mempengaruhi inflasi secara positif maupun negative, apakah kecendrungannya bersifat adaptif atau forward looking. Hal ini terlihat dari perilaku pembentukan harga di tingkat produsen dan pedagang terutama pada saat menjelang hari besar keagamaan dan penentuan upah minimum regional. Ketiga, Dorongan permintaan (demand pull inflation). Apabila terjadi permintaan agregat yang lebih cepat dari pada potensi produksi perekonomian maka akan mengakibatkan terjadinya inflasi yang yang disebabkan oleh dorongan permintan atau demand pull inflation (BI, 2014).

Inflasi bisa disebabkan fenomena structural (cost push inflation) dan fenomena moneter, hal ini berdasarkan studi di negara-negara berkembang bahwa inflasi disebabkan 
oleh kedua factor tersebut dimana pada umumnya agraria menjadi struktur ekonomi negara-negara berkembang (negara dunia ketiga). Implikasi yang terjadi apabila terjadi gagal panen, kurs valuta asing, utang luar negeri dan lain sebagainya dapat mengakibatkan fluktuasi harga di pasar domestic. Fenomena struktural yang disebabkan oleh kesenjangan atau kendala struktural dalam perekonomian di negara berkembang, sering disebut dengan structural bottlenecks. Seringkali Strucktural bottleneck berada pada tiga area, yaitu: 1 . Cadangan valuta asing yang terbatas (kecil). Terbatasnya cadangan valuta asing akibat dari impor lebih besar dari pada ekspor. Akibat dari lambatnya laju pembangunan sektor industri, seringkali menyebabkan laju pertumbuhan supply barang tidak dapat mengimbangi laju pertumbuhan permintaan. 2. Terbatasnya Pengeluaran pemerintah. Defisit anggaran seringkali mempengaruhi negara untuk mengambil keputusan pinjaman dari luar negeri. Defisit yang terjadi bisa disebabkan karena penerimaan negara yang rendah sehingga berdampak terhadap pembiayaan pemerintah yang terbatas. Pemerintah hanya cukup untuk membiayai pembangunan yang berdampak pada defisit anggaran pembiayaan. Fenomena inflasi di negara negara yang sedang berkembang kadangkala menjadi suatu fenomena jangka panjang, yang membutuhkan waktu yang panjang dalam menyelesaikan persoalan inflasi. Bila jumlah uang yang tersedia untuk investasi melimpah, menyebabkan harga uang (suku bunga) akan murah, maka volume investasi akan meningkat. Dengan meningkatnya volume investasi, volume produksi akan meningkat pula.

Target inflasi adalah tingkat inflasi yang harus dicapai oleh Bank Indonesia berkoordinasi dengan Pemerintah. Berdasarkan UU Bank Indonesia, target inflasi ditetapkan oleh Pemerintah. Target inflasi ini dipertimbangkan sebagai patokan untuk bisnis dan publik dalam melakukan kegiatan ekonomi masa depan mereka dan dengan demikian membawa inflasi ke tingkat yang rendah dan stabil. Pemerintah dan Bank Indonesia berkomitmen kuat untuk mencapai target inflasi yang ditetapkan melalui koordinasi kebijakan yang secara konsisten melacak target ini. Salah satu ukuran pengendalian inflasi untuk menghasilkan inflasi yang rendah dan stabil adalah membentuk dan membimbing ekspektasi inflasi publik menuju jangkar target inflasi yang telah ditetapkan.

Indeks Produk Industri (IPI). IPI adalah proxy dari pendapatan nasional atau GDP diperoleh dari SPI. Indeks Produksi Industri (IPI) merupakan indikator ekonomi yang bertujuan untuk menilai pergerakan nilai total inflasi. Perubahan nilai total inflasi disesuaikan dengan output produksi dari industry akan tetapi tidak termasuk indsutri kontstruksi. IPI bertujuan untuk mengukur tingkat hasil produksi negara. Data IPI dapat diperoleh dari Biro Pusat Statistik yang mencakup semua input dan output fisik yang digunakan dalam proses produksi. IPI adalah indikator frekuensi tinggi yang penting dari formal kegiatan manufaktur dalam ekonomi, tren kontras dalam tingkat pertumbuhan menimbulkan kesulitan dalam memahami pertumbuhan kinerja (Pandey, 2018).

Financing to Deposit Ratio (FDR). Standar ideal yang ditetapkan oleh Bank Indonesia dalam mengelola rasio Financing to Deposit Ratio (FDR) adalah $80 \%$ hingga $110 \%$ (Wahyu, 2016). Standar ini adalah standar yang menjadi pedoman bagi bank dalam mengelola FDR. Apabila rasio Financing to Deposit Ratio (FDR) berada diatas 90\%, hal ini mengindikasikan bahwa bank menyalurkan pembiayaan sebesar $90 \%$ dari seluruh dana 
yang dihimpun. Apabila rasio ini 50\% maka dapat disimpulkan bahwa bank hanya dapat menyalurkan sebesar 50\%. Idealnya bahwa bank mengikuti standar yang ditetapkan oleh bank Indonesia untuk menjaga likuiditas. Bank memiliki fungsi utama yaitu sebagai lembaga intermediasi (perantara) kepada masyarakat. Bank akan menghimpun pihak yang kelebihan dana dan menyalurkannya kepada pihak yang membutuhkan dana. Bank menggunakan FDR sebagai rasio yang yang menunjukkan tingkat likuiditas bank dalam memenuhi hak deposan. Financing to Deposit Ratio (FDR) merupakan rasio yang digunakan untuk mengukur likuiditas suatu bank dalam membayar kembali penarikan dana yang dilakukan deposan dengan mengandalkan pembiayaan yang diberikan sebagai sumber likuiditasnya. Dengan penyaluran Dana Pihak Ketiga (DPK) yang besar maka pendapatan bank atau Return on Asset (ROA) akan semakin meningkat, sehingga Financing to Deposit Ratio (FDR) berpengaruh positif terhadap Return on Asset (ROA). Namun rasio FDR yang semakin tinggi akan menyebabkan lemahnya kemampuan likuiditas bank (Rivai dan Arifin, 2010). Hal ini karena semakin sedikit dana likuid dan resiko tidak terpenuhinya kemampuan membayar penarikan nasabah lebih tinggi.

\section{METODELOGI}

Penelitian ini menganalisis data dengan metode autoregressive distributed lag (ARDL) dijalankan dengan Software E-Views. Pendekatan penelitian ini menggunakan pendekatan kuantitatif dengan metode regresi berganda. Variabel independen (X) adalah Market share perbankan syari'ah, sedangkan Variable dependennya adalah Industrial Production Index (GDP), suku bunga (intrest rate), inflasi Return on Asset (ROA), dan Rasio Pembiayaan terhadap Deposito (FDR). Data didapatkan dari laporan keuangan Otoritas Jasa Keuangan (OJK). Penelitian ini menggunakan data bulanan dari tahun 2011 sampai tahun 2018. Data yang dikumpulkan adalah market share, inflasi, IPI, Suku Bunga, ROA, FDR. Langkah awal yang dilakukan adalah melakukan plot pada masing- masing data lalu dilanjutkan dengan melakukan uji stasioneritas pada ragam dan rata-rata.

Setelah itu, dilakukan analisis kointegrasi dengan mengunakan metode Bounds Testing Cointegration dengan pendekatan ARDL. Metode ini memiliki keunggulan karena tidak mempermasalahkan variabel-variabel yang terdapat pada model bersifat I (0) atau I (1). Melalui metode Bounds Testing Cointegration menunjukkan pendekatan ARDL akan menghasilkn kooefisien jangka panjang dengan estimasi yang konsisten yang secara asimtotik normal. 


\section{ANALISIS HASIL DAN PEMBAHASAN}

Tabel 1. Statistic Descriptive

\begin{tabular}{l|cccccc}
\hline & $\Delta$ MS & INFLASI & $\Delta$ IPI & INT & $\Delta$ ROA & $\Delta$ FDR \\
\hline Mean & 0.045557 & 0.386563 & 0.447604 & 0.061875 & 0.012734 & 0.913188 \\
Median & 0.045800 & 0.265000 & 0.610000 & 0.060000 & 0.011250 & 0.905800 \\
Maximum & 0.055900 & 3.290000 & 15.25000 & 0.077500 & 0.025200 & 1.048300 \\
Minimum & 0.032000 & -0.450000 & -15.50000 & 0.042500 & 0.000800 & 0.776300 \\
Std. Dev. & 0.005705 & 0.531660 & 3.687295 & 0.011092 & 0.006223 & 0.081950 \\
\hline
\end{tabular}

Tabel 1 melaporkan statistik ringkasan dari variabel yang digunakan dalam analisis ini. Untuk setiap variabel, mean, median, dan standar deviasi, dilaporkan. Dari tabel diatas, dapat diketahui bahwa suku bunga memiliki nilai rata-rata yang paling tinggi yaitu $6,19 \%$. Sementara itu, rata-rata market share perbankan syari'ah sebesar 4,55\% dan ratarata profitabilitas perbankan syari'ah sebesar $1,27 \%$.

Kointegrasi dapat digunakan sebagai alat analisis untuk solusi data time series yang tidak stasioner. Khususnya untuk penelitian dengan pendekatan ARDL, metode uji kointegrasi Bounds Testing Cointegration digunakan untuk mengetahui adanya kointegrasi pada model sehingga dapat diketahui hubungan jangk panjang antar variabel dalam persamaan.

Table 2. Bound Test Cointegration

\begin{tabular}{lcc} 
F-statistic & 3.259545 & 5 \\
Significance & I0 Bound & I1 Boun \\
\hline \hline $10 \%$ & 2.26 & 3.35 \\
$5 \%$ & 2.62 & 3.79 \\
$2.5 \%$ & 2.96 & 4.18 \\
$1 \%$ & 3.41 & 4.68
\end{tabular}

Dari tabel diatas diperoleh informasi bahwa nilai F-Statistic Value > nilai I (0) dan I (1) yaitu $5>2.26$ dan 3.35. Sehingga menolak Ho. Artinya dapat digunakan untuk mengetahui bahwa masing-masing model memiliki hubungan keseimbangan jangka panjang, serta MS, Inflasi, IPI, INT, ROA, FDR, telah stasioner.

Agar model ARDL yang diestimasi dapat terhindar dari pelangggaran asumsiasumsi dasar ekonometri maka perlu dilakukan uji diagnosis. Dalam penelitian ini 
dilakukan uji asumsi klasik yang terdiri dari tiga uji yaitu uji multikolinieritas, uji heteroskedastisitas, dan uji autokorelasi. Apabila model telah terhindar dari asumsi ekonometri, maka analisis hasil regresi dapat dilanjutkan.

Tabel 3. Hasil Estimasi Jangka Pendek

Cointegrating Form

\begin{tabular}{|c|c|c|c|c|}
\hline Variable & Coefficient & Std. Error & t-Statistic & Prob. \\
\hline $\mathrm{D}(\mathrm{MS}(-1))$ & -0.434649 & 0.106324 & -4.087958 & 0.0001 \\
\hline $\mathrm{D}(\mathrm{MS}(-2))$ & -0.170644 & 0.111374 & -1.532172 & 0.1310 \\
\hline $\mathrm{D}(\mathrm{MS}(-3))$ & -0.011933 & 0.105401 & -0.113220 & 0.9103 \\
\hline $\mathrm{D}(\mathrm{MS}(-4))$ & -0.237451 & 0.107313 & -2.212687 & 0.0309 \\
\hline $\mathrm{D}(\mathrm{MS}(-5))$ & -0.127307 & 0.097972 & -1.299419 & 0.1990 \\
\hline D(INFLASI) & 0.000451 & 0.000149 & 3.020567 & 0.0038 \\
\hline $\mathrm{D}(\mathrm{IPI})$ & -0.000016 & 0.000024 & -0.670786 & 0.5051 \\
\hline $\mathrm{D}(\mathrm{IPI}(-1))$ & 0.000066 & 0.000034 & 1.937685 & 0.0576 \\
\hline $\mathrm{D}(\mathrm{IPI}(-2))$ & 0.000073 & 0.000035 & 2.096205 & 0.0405 \\
\hline $\mathrm{D}(\mathrm{IPI}(-3))$ & -0.000000 & 0.000032 & -0.009256 & 0.9926 \\
\hline $\mathrm{D}(\mathrm{IPI}(-4))$ & -0.000036 & 0.000023 & -1.557003 & 0.1250 \\
\hline $\mathrm{D}(\mathrm{INT})$ & -0.063308 & 0.038215 & -1.656619 & 0.1031 \\
\hline $\mathrm{D}(\mathrm{INT}(-1))$ & -0.079715 & 0.059143 & -1.347822 & 0.1830 \\
\hline $\mathrm{D}(\mathrm{INT}(-2))$ & -0.057449 & 0.061366 & -0.936167 & 0.3531 \\
\hline $\mathrm{D}(\mathrm{INT}(-3))$ & 0.041479 & 0.059923 & 0.692204 & 0.4916 \\
\hline $\mathrm{D}(\mathrm{INT}(-4))$ & -0.093043 & 0.061657 & -1.509026 & 0.1368 \\
\hline $\mathrm{D}(\mathrm{INT}(-5))$ & 0.099205 & 0.041200 & 2.407888 & 0.0193 \\
\hline $\mathrm{D}(\mathrm{ROA})$ & 0.046573 & 0.026598 & 1.750990 & 0.0853 \\
\hline $\mathrm{D}(\mathrm{FDR})$ & -0.012541 & 0.003662 & -3.424701 & 0.0011 \\
\hline $\mathrm{D}(\mathrm{FDR}(-1))$ & -0.004624 & 0.004912 & -0.941434 & 0.3505 \\
\hline $\mathrm{D}(\mathrm{FDR}(-2))$ & 0.006226 & 0.004806 & 1.295307 & 0.2004 \\
\hline $\mathrm{D}(\operatorname{FDR}(-3))$ & -0.007770 & 0.004895 & -1.587443 & 0.1179 \\
\hline $\mathrm{D}(\mathrm{FDR}(-4))$ & -0.000106 & 0.005029 & -0.020996 & 0.9833 \\
\hline $\mathrm{D}(\mathrm{FDR}(-5))$ & -0.002025 & 0.004914 & -0.412120 & 0.6818 \\
\hline $\mathrm{D}(\mathrm{FDR}(-6))$ & 0.009082 & 0.003893 & 2.332790 & 0.0232 \\
\hline CointEq(-1) & -0.067793 & 0.028448 & -2.383059 & 0.0205 \\
\hline
\end{tabular}


Hasil estimasi diatas menunjukkan bahwa inflasi dalam jangka pendek memiliki pengaruh positif yang signifikan terhadap market share perbankan syari'ah. Kemampuan bank syariah dalam menghadapi inflasi menunjukkan bahwa bank syari'ah lebih kuat dan lebih menarik daripada bank konvensional. Alasannya adalah bahwa bank syariah menerapkan prinsip bagi hasil dalam operasi perbankannya. (Arif, 2017). Hal ini juga karena perbankan syariah mengetahui target inflasi yang ditetapkan oleh pemerintah sehingga perbankan syariah dapat mengantisipasi pengaruh inflasi yang terjadi melalui manajemen resiko perbankan. Dalam jangka panjang, Inflasi tidak berpengaruh signifikan terhadap market share perbankan syariah. Inflasi yang terjadi tidak berimbas pada peningkatan dan penurunan market share pebankan syari'ah (Arif, 2015).

Tabel 4. Hasil Estimasi Jangka Panjang

\begin{tabular}{crrrr}
\hline \hline Variable & Coefficient & \multicolumn{1}{c}{ Std. Error } & \multicolumn{1}{c}{ t-Statistic } & \multicolumn{1}{c}{ Prob. } \\
\hline \hline INFLASI & 0.000616 & 0.002920 & 0.211139 & 0.8335 \\
IPI & -0.002408 & 0.002370 & -1.016232 & 0.3138 \\
INT & -0.606076 & 0.194094 & -3.122587 & 0.0028 \\
ROA & 0.069112 & 0.397799 & 0.173736 & 0.8627 \\
FDR & -0.008744 & 0.024656 & -0.354644 & 0.7242 \\
\hline \hline
\end{tabular}

Dalam jangka panjang dan jangka pendek, Suku bunga berpengaruh negatif yang signifikan terhadap market share perbankan syariah. Peningkatan suku bunga mengurangi market share perbankan syariah karena suku bunga yang tinggi akan mengurangi nilai asset perbankan syariah dan meningkatkan resiko perpindahan nasabah (displacement risk) pada perbankan syari'ah. Walaupun pada dasarnya Bank syariah tidak mengenal adanya penetapan suku bunga. Peningkatan bunga akan meningkatkan resiko bagi perbankan syari'ah sehingga perbankan syari'ah akan mengalami kesulitan dalam menghadapi resiko kenaikan suku bunga tersebut. Selain itu, Suku bunga yang tinggi dapat mengurangi keuntungan dan memberikan kerugian bagi perbankan syari'ah. Setiap kali terjadi kenaikan suku bunga, maka bank syariah akan mendapatkan dampak negatif terhadap dari kejadian tersebut (Hutapea dan Kasri, 2010).

Dampak negatif suku bunga mengakibatkan perbankan syariah tidak mampu meningkatkan market sharenya sehingga suku bunga yang tinggi adalah hal yang tidak menguntungkan perbankan syariah. Disamping itu, perbankan syariah akan mengalami kesulitan likuiditas karena pihak ketiga banyak yang memindahkan modalnya ke perbankan konvensional. Hal yang unik muncul bahwa Meskipun bank syariah menawarkan bagi hasil yang tinggi, tidak terdapat dampak yang signifikan terhadap peningkatan pendanaan perbankan syari'ah ketika terjadi kenaikan suku bunga yang tinggi (Chong dan Liu, 2009). Kejadian ini disebabkan karena perbankan syari'ah menerapkan prosedur yang rumit dan biaya administrasi yang lebih tinggi dari perbankan konvensional.

IPI sebagai proxy gross domestic product memiliki pengaruh positif terhadap perbankan syari'ah dalam jangka pendek khususnya pada lag 1 dan lag ke 2 namun tidak memiliki pengaruh dalam jangka panjang terhadap pertumbuhan market share perbankan 
islam. Hal ini juga ditunjukkan dengan hasil penelitian lainnya bahwa tingkat produksi tidak mempengaruhi pertumbuhan market share perbankan syari'ah (Arif, 2015). Bank syari'ah memiliki keterbatasan modal sehingga untuk memenuhi tingkat permintaan pembiayaan yang semakin tinggi karena pertumbuhan ekonomi, bank syari'ah memberikan sesuai dengan jumlah modal yang dimilikinya, akibatnya pertumbuhan ekonomi tidak mempengaruhi pertumbuhan market share perbankan syari'ah dalam jangka panjang.

ROA berpengaruh positif terhadap market share perbankan syariah dalam jangka pendek. Salah satu penilaian utama perusahaan adalah tingkat keuntungan. Hal yang sama juga berlaku dalam perbankan syari'ah. Perbankan syariah yang memiliki tingkat keuntungan yang tinggi akan mendapatkan kepercayaan masyarakat karena bagi hasil yang diberikan sesuai dengan ekspektasi yang dibutuhkan. Performa perbankan syariah akan semakin meningkat dengan meningkatnya keuntungan yang didapatkan perbankan syari'ah. Hal yang perlu diketahui juga Bank syari'ah mendapatkan keuntungan dari penguasaan pasar yang dimilikinya. Dengan meningkatnya keuntungan maka market share perbankan syariah akan semakin meningkat, dan secara lansung mempengaruhi kontribusi perbankan syariah kepada ekonomi (Mirzaei, 2010). Meningkatnya aset perbankan syariah akan meningkatkan pangsa pasar perbankan syariah. Oleh karena itu, perbankan syari'ah perlu memberikan pembiayaan yang efektif kepada masyarakat. Perbankan syariah dapat menggunakan keuntungan yang didapatkan untuk melakukan ekspansi pasar sehingga pangsa pasar perbankan syari'ah semakin luas (Saputra, 2014).

Walaupun ROA perbankan syari'ah berpengaruh positif dalam jangka pendek, akan tetapi ROA tidak memiliki pengaruh yang signifikan bagi pertumbuhan market syari'ah dalam jangka panjang. Penelitian yang lain juga mengungkapkan hal yang sama bahwa ROA tidak berdampak terhadap keuntungan perbankan syari'ah (Arif dan Yuke, 2017). Hal tersebut disebabkan karena keuntungan yang didapatkan dimamfaatkan untuk mengantisipasi terjadinya risiko pasar yang dapat merugikan perbankan syariah.

FDR berpengaruh positif terhadap market share perbankan syariah dalam jangka pendek, tetapi tidak memiliki pengaruh signifikan dalam jangka panjang. Pembiayaan perbankan syariah akan meningkatkan asset perbankan syariah. Perbankan syariah memperluas market share yang dimilikinya melalui pembiayaan. Sehingga semakin luas jangkauan pembiayaan yang dilakukan oleh perbankan syariah maka market share perbankan syariah akan semakin meningkat. Dalam hal ini, Diperlukan strategi marketing melalui segmentasi pasar atau dengan marketing mix agar market share perbankan syariah dapat meningkat dengan cepat. Dalam menyalurkan pembiayaannya, bank syariah dapat mengupayakan tidak terjadinya pembiayaan bermasalah atau meningkatkan pengembalian pembiayaan tidak lancar secara aktif sehingga akan meningkatkan pendapatan bank syariah sehingga keuntungan akan meningkat. Apabila tingkat pengembalian pembiayaan yang telah disalurkan tidak lancar maka akan mengakibatkan menurunnya kemampuan bank dalam membayar kembali kewajiban kepada nasabah yang telah menanamkan dananya dengan pembiayaan yang disalurkan kepada para debiturnya, sehingga kepercayaan masyarakat untuk menanamkan dananya pada bank syariah akan menurun. Keuntungan yang meningkat ini berujung pada peningkatan pangsa pasar aset bank syariah. FDR memiliki dampak positif terhadap market share perbankan syari'ah sesuai dengan penelitian yang menemukan bahwa FDR menentukan market share perbankan syari'ah (Saputra, 2014). 
Pembiayaan yang diberikan oleh perbankan syariah akan meningkatkan total asset perbankan syari'ah. Meningkatknya FDR bank syariah dalam batas tertentu, maka semakin meningkat pula laba bank yang pada akhirnya menimbulkan peningkatan pembiayaan dan mengakibatkan tingginya market share bank syariah, dengan asumsi bank menyalurkan dananya untuk pembiayaan yang efektif. Selain itu, FDR tidak memiliki pengaruh dalam jangka panjang sesuai dengan penelitian (Purboastuti et al., 2015) bahwa FDR tidak memiliki dampak terhadap pertumbuhan asset perbankan syari'ah (Arif 2015; Syafrida dan Abror 2011). Alasannya adalah karena pembiayaan diberikan secara tidak efektif. Dalam hal pembiayaan, perbankan syari'ah perlu melihat efektifitas pembiayaan yang diberikan kepada nasabah agar dapat meningkatkan total asset yang dimilikinya dengan system control internal. (Wardiwiyono, 2012). Total asset yang semakin berkembang akan meningkat market share perbankan syari'ah.

\section{KESIMPULAN}

Market share perbankan syariah adalah salah satu kontributor terbesar terhadap kemajuan market share keuangan islam. Penelitian ini bertujuan untuk mengkaji secara komprehensif pertumbuhan market share perbankan syari'ah dalam interaksi dinamik jangka pendek dan jangka panjang. Variable independen yang digunakan dalam penelitian ini adalah inflasi, industrial production index (IPI), intrest rate, Return of Asset (ROA) dan financing to Deposite Ratio (FDR).

Suku bunga berpengaruh negatif yang signifikan terhadap market share perbankan syariah. Peningkatan suku bunga mengurangi market share perbankan syariah karena suku bunga yang tinggi akan mengurangi nilai asset perbankan syariah dan meningkatkan resiko displacement pada perbankan syari'ah. Setiap kali terjadi kenaikan suku bunga, maka bank syariah akan mendapatkan dampak negatif terhadap dari kejadian tersebut.

Dalam jangka pendek, Inflasi, ROA, FDR Berpengaruh positif terhadap market share perbankan syari'ah namun tidak memiliki dampak jangka panjang. Terhadap market share perbankan syari'ah. Ketiga variable tersebut hanya mempengaruhi market share perbankan syari'ah dalam jangka pendek. Di sisi lain, IPI sebagai proxy produk domestic product (gross domestic product) tidak memiliki dampak jangka pendek dan jangka panjang terhadap pertumbuhan market share perbankan islam. Penelitian ini menunjukkan bahwa bank sentral harus mengatur suku bunga dengan tepat agar tercipta lingkungan yang kondusif bagi perbankan. Selain itu Perbankan syari'ah perlu meningkatkan manajemen resiko agar terhindar dari resiko bunga.

\section{DAFTAR PUSTAKA}

Arif Al Mohammad Nur Rianto and Yuke Rahmawati. (2018). Determinant Factors of Market Share: Evidence from the Indonesian Islamic Banking Industry. Problems and Perspectives in Management, 16(1), 392-398.

Arif Al Mohammad Nur Rianto. (2015). Impact Of Spin-Off Policy On The Asset Growth On Indonesian Islamic Banking Industry. Journal of Islamic Economics, Banking and Finance, Vol-11, No. 4, Octo-Dec, 2015. 
Arif Al Mohammad Nur Rianto. (2017) Spin-off and Market Share in the Indonesian Islamic Banking Industry: a Difference in Difference Analysis. Management \& Marketing. Challenges for the Knowledge Society. Vol. 12, No. 4.

Bitar (2018). The Determinants of Islamic Bank Capital Decisions. Emerging Markets Review 35, 48-68.

Bulski, M. (2013), "Interest Rate Risk in Nonfinancial Company”, Studia Ekonomiczne, Vol. 127, pp. 49-64.

Chong Beng Soon, Ming-Hua Liu. (2009). Islamic banking: Interest-free or interestbased? Pacific-Basin Finance Journal Volume 17, Issue 1, January 2009, Pages $125-144$

Deputi Bidang Ekonomi. (2018). Masterplan Ekonomi Syariah Indonesia 2019-2024. Badan Perencanaan Pembangunan Nasional

Godspower-Akpomiemie, E.I. (2012). "Market Interest Rate Fluctuations: Impact on the Profitability of Commercial Banks, Master's Dissertation”, University of the Witwatersrand, Witwatersrand.

Hendra Sesario Tri Nur dan Hartomo Sosro Deny Dwi. (2017). Jurnal Bisnis \& Manajemen Vol. 17, No. 2,: 35 - 50.

Hutapea Erwin G. and Rahmatina A. Kasri. (2010). Bank Margin Determination: a Comparison Between Islamic and Conventional Banks in Indonesia. International Journal of Islamic and Middle Eastern Finance and Management Vol. 3 No. 1,

Ikatan Bankir Indonesia. (2016). Manajemen Kesehatan Bank Berbasis Risiko. 1st. Jakarta: PT Gramedia Pustaka Utama.

Janakiraman. B. (2019). Negative and Low Deposit Rates and Penalty on Savers The Impacts of Monetary Policy in the 21st Century: Perspectives from Emerging Economies.

Julianti, Friska. (2013). Analisis Pengaruh Inflasi, Nilai Tukar dan BI Rate terhadap Tabungan Mudharabah pada Perbankan Syariah. Skripsi. Jakarta. Fakultas Ekonomi dan Bisnis UIN Syarif Hidayatullah Jakarta.

Mirzaei, A. (2010). The Effect of Market Power on Stability and Performance of Islamic and Conventional Banks. Islamic Economic Studies, 18(1\&2), 45-82.

Naylah, Maal. (2010). Pengaruh Struktur pasar Terhadap Kinerja Industri Perbankan di Indonesia.Tesis Program Pasca Sarjana, Universitas Diponegoro.

Pandey (2018). What does the new 2011-12 IIP Series Tell About the Indian Manufacturing Sector? Indian Growth and Development Review Vol. 11 No. 2.

Purboastuti, N., Anwar, N., dan Suryahani, I. (2015). Pengaruh Indikator Utama Perbankan Terhadap Pangsa Pasar Perbankan Syariah (The Influence of Main Banking Indicator to Islamic Bank's Market Share). JEJAK: Journal of Economics and Policy, 8(1), 13-22.

Rusydiana, A. S. (2016). Analisis Masalah Pengembangan Perbankan Syariah di Indonesia: Aplikasi Metode Analytic Network Process (The Development Problems Analysis of Islamic Banking in Indonesia: Application of Analytic Network Process Method). Esensi: Jurnal Bisnis dan Manajemen, 6(2), 237-246.

Saputra, B. (2014). Faktor-Faktor Keuangan yang Mempengaruhi Market Share Perbankan Syariah di Indonesia (The Financial Factors That Influence Islamic Bank's Market Share in Indonesia). Akuntabilitas, 7(2), 123-131. 
Sari, M. D., Bahari, Z., and Hamat Z. (2016). History of Islamic Bank in Indonesia: Issues Behind Its Establishment. International Journal of Finance and Banking Research, 2(5), 178-184.

Supriyanti, Neni. (2009). Analisis Pengaruh Inflasi dan Suku Bunga BI terhadap Kinerja Keuangan PT. Bank Mandiri, Tbk. Berdasarkan Rasio Keuangan. Jakarta. Universitas Gunadarma.

Syafrida Ida dan Ahmad Abror (2011). Faktor-Faktor Internal dan Eksternal yang Mempengaruhi Pertumbuhan Aset Perbankan Syariah di Indonesia. Jurnal ekonomi dan bisnis, VOL 10, 19-24

Temewu, Riana Christel., dan Stanly W. Alexander. (2014). Pengaruh Penerapan Good Corporate Governance terhadap Profitabilitas pada Perusahaan Perbankan yang terdaftar di BEI Periode 2009-2013.

Thoriq Gunara. (2007). Marketing Muhammad"Strategi Andal dan Jitu Praktik Bisnis Nabi Muhammad saw” Bandung: Masania Prima

Wahyu Didin Rasyidin. (2016). Financing to Deposit Ratio (Fdr) Sebagai Salah Satu Penilaian Kesehatan Bank Umum Syariah (Study Kasus Pada Bank BJB Syariah Cabang Serang) Islami conomic: Jurnal Ekonomi Keuangan dan Bisnis Islam Page: $19-36$.

Wardiwiyono Sartini. (2012). Internal Control System for Islamic Micro Financing: An Exploratory Study of Baitul Maal wat Tamwil in the City of Yogyakarta Indonesia. International Journal of Islamic and Middle Eastern Finance and Management.

Weill, L. (2011), "Do Islamic Banks Have Greater Market Power?" Comparative Economic Studies, Vol. 53, pp. 291-306.

Wouters, P. (2009). Islamic Banking in Turkey, Indonesia and Pakistan: A Comparison with Malaysia. Islamic Finance News, 4(42).

www.BI.go.id.

Yudiana, Fetria Eka. (2014). Manajemen Pembiayaan Bank Syariah. Salatiga: STAIN Salatiga Press 